\title{
Interpretation of sustainability in the utilization of renewable energy sources
}

\author{
Mihály Dombi ${ }^{1}$ - István Kuti ${ }^{1}$ - Péter Balogh ${ }^{2}$ \\ ${ }^{1}$ University of Debrecen, Centre for Agricultural and Applied Economic Sciences, Faculty of Applied Economics and Rural Development, \\ Institute of Economic Theory \\ ${ }^{2}$ University of Debrecen, Centre for Agricultural and Applied Economic Sciences, Faculty of Applied Economics and Rural Development, \\ Institute of Economic Analytical Methodology and Applied Informatics \\ H-4024 Debrecen Böszörményi út. 138. \\ dombi@agr.unideb.hu
}

Keywords: sustainability; renewable energy sources; choice experiment

\section{SUMMARY}

The utilization of renewable energy sources (res) is crucial regarding to sustainable reconstruction of energy systems. The target is a balanced, sustainable development of Hungarian energy management considering equally the ecological, social and economic aspects. There are many different technologies of utilization of res varied by sources, conversion processes, size and products. The comparison of each technology and their sustainability assessment are required by the importance of efficient remodeling of energy infrastructure. The group of attributes was composed by numerous important parameters in the course of our analysis with the choice experiment (ce) methodology. The estimation of each attributes' influence on the individual's preferences and choices was possible by this method and the preferences of the statistical population was concluded. So thus the utility derived from each attribute was estimated. The result of the ce analysis for the population of experts is demonstrated in the current phase of our research.

\section{INTRODUCTION}

The long-term existence of the human civilization is possible only by the harmonization of environmental, social and economic impacts of humanity and the opportunities secured by the bio-geosphere so thus the sustainable development. In this process the remodeling of current energy system is absolute necessary. The system is not sustainable because of irrational energy requirements and economic growth based energy demand, the population growth as well as the short- and long-run insecurity of the resources. The increase of efficiency, the reforming of consumption patterns and the restructuring of energy system are targeted simultaneously.

The requirements of sustainability at the actual level of knowledge are fulfilled only by the renewable energy sources (RES) therefore the role of these sources in the energy system has to be increased significantly. The efficiency of energy and environmental policy is a key aspect in the effect of this process. The complex comparison of the technologies according to the ecological, social and economic impacts is allowed by the sustainability assessment which is a useful tool to support the orientation of these policies.

The sustainability assessment of RES was attempted from many aspects. Descriptions were used in several studies (Rio and Burguillo, 2008; Rio and Burguillo, 2009; Varga and Homonnai, 2009). Methods of scoring (Lukács, 2009) and ranking (Evans et al., 2009) are also possible way of assessment as well as monetarization (Gács, 2010; Ulbert and Takács, 2008) which is less subjective methodology then the others. The most complex assessment method up to now is the "Multi Criteria Decision Making" used by Rideg et al. (2009a; 2009b). The weight of environmental, social and economic aspects was not defined in this complex valuation, although it is a key to comparison. The exploration of these weights is aimed in this study - it is the interpretation of sustainability in the case of utilization of renewable energy sources.

\section{METHODOLOGY}

To assist with the defining of energy policy priorities is the main goal of research with the exploration of aspect weights. An economic valuation method, the choice experiment method (CE) was used because of its suitability to valuating the changes in welfare contrary to other stated preference methods. This methodology is based on Lancaster's characteristics theory of value and the McFadden's random utility theory.

In order to link actual choices with the theoretical construct utility, the random utility framework is used. According to random utility theory the $i$ th respondent is assumed to obtain utility $U_{i j}$ from the $j$ th alternative in choice set C. $U_{i j}$ is supposed to comprise a systematic component $\left(V_{i j}\right)$ and a random error component $\left(\varepsilon_{i j}\right)$ :

$\mathrm{U}_{\mathrm{ij}}=\mathrm{V}_{\mathrm{ij}}+\varepsilon_{\mathrm{ij}}$

Selection of alternative $h$ by individual $i$ over other alternatives implies that the utility $\left(U_{i h}\right)$ of that alternative is greater than the utility of the other alternatives $j$ :

$\left.P_{\text {ih }}=\operatorname{Prob}\left(V_{\text {ih }}+\varepsilon_{\text {ih }}\right\rangle V_{i j}+\varepsilon_{i j}\right) \quad \forall h, j \in C, j \neq h$. 
Assuming that the error components are distributed independently and identically (IID) and follow the Gumbel distribution, the probability that alternative $h$ would be chosen is calculated in the conditional logit model (CL) as

$P_{i h}=\frac{\exp \left[\mu V_{i h}\right]}{\sum_{j \in C} \exp \left[\mu V_{i j}\right]}$

where $\mu$ is a scale parameter which is commonly normalized to 1 for any one dataset. The systematic part of utility of the $j$ th alternative is assumed to be a linear function of attributes (Mayerhoff et al., 2009). The scope of the CE method is the estimation of utility $\left(V_{j}\right)$ connected with the attributes $(A)$ of each alternative which is chosen by the individual:

$\mathrm{V}_{\mathrm{j}}=\mathrm{ASC}_{\mathrm{V}}+\beta_{1} \mathrm{~A}_{1}+\beta_{2} \mathrm{~A}_{2}+\ldots+\beta_{\mathrm{n}} \mathrm{A}_{\mathrm{n}}$

ASC is an 'alternative specific constant'. The $\beta$ values are the coefficients associated with each of the attributes (Bennett and Blamey, 2001). The attribute coefficients $(\beta)$ and the trade-off ratio between the attributes are resulted by this methodology. They are presenting the preferences of the respondent and so thus the whole population. The common attributes of the alternatives and their levels are defined before the examination.

The first applications of CE were published in early 1980s in the fields of marketing and transport research (Krajnyik, 2008). Simultaneously with the development of the method, the scope of adaptations was expanded. There are many publications in tourism, landscape and ecological economic issues supported by CE. The energy sector was analyzed also from ecological point of view firstly by Roe et al. (2001). An application of conjoint analysis was used, the respondents chose between two alternatives. The price, the contact terms, the fuel mix and the air pollution were the attributes. The highest willingness to pay (WTP) ${ }^{1}$ was observable by 'the increase in renewable fuel'. The possible power production investments in Scotland were assessed by Bergmann et al. (2006). Preferences were estimated by the CE method through 219 returned questioners regarding to attributes of landscape, wildlife, air pollution, employment and price of electricity. The WTP of 'decrease in air pollution' was the highest. The WTP of employment was surprisingly not significant even at $10 \%$ level. We expect the labour attribute at one of the highest level in preferences in Hungary. The WTP of the residents of Bath, England was examined by Longo et al. (2008) for promotion of renewable energy sources. The attributes of the CE analyze were GHG emissions, black-outs, employment and increase in electricity bill. According to these results the $\beta$ coefficients of the price and the black-outs were negative which is natural by harmful impacts. The WTP for the 'decrease in GHG emission' was the highest. Korean energy investment alternatives were analyzed by Ku and Yoo (2010). The attributes used were the same as in (Bergmann et al. 2006) but the results show somewhat higher preferences in the employment attribute.

\section{STUDY DESIGN}

In any survey fulfilled by $\mathrm{CE}$, the respondents are asked to choose between selected (2-4) hypothetic alternatives regarding to investments, goods or policies. The attributes and the attribute levels have to be described first. This attributes which were defined on the basis of the relevant literature are shown in Table 1 . The most important environmental, social and economic impacts were collected. They are relevant, understandable and useful for policy making.

Table 1

Attributes and attribute levels

\begin{tabular}{|l|l|l|}
\hline \multicolumn{1}{|c|}{ Attribute } & \multicolumn{1}{c|}{ Description } & \multicolumn{1}{c|}{ Levels } \\
\hline $\begin{array}{l}\text { Decrease in GHG } \\
\text { emission }\end{array}$ & $\begin{array}{l}\text { Decrease in GHG emission due to using of each technology (LCA approach) in comparison to } \\
\text { conventional technology (\%). }\end{array}$ & 5; 50; 90 \\
\hline Land demand & Amount of technological demand on agricultural, forest or nature conservation used land. & Low; High \\
\hline Energy efficiency & Ratio of used and produced energy (LCA approach, O/I) (\%) & 10,$30 ; 60$ \\
\hline $\begin{array}{l}\text { Other harmful } \\
\text { ecological impacts }\end{array}$ & Direct and indirect impacts of the utilization (e. g. landscape, noise pollution) & $\begin{array}{l}\text { Marginal; Great } \\
\text { importance }\end{array}$ \\
\hline Increase in costs & Investment and operation costs in comparison to conventional technology (\%) & $5 ; 30 ; 60$ \\
\hline New jobs & New jobs due to utilization sources by each technology (persons/100 TJ) & $2 ; 10 ; 20$ \\
\hline Local income & Income realized by local citizens, enterprises or local government due to utilization (th. HUF/TJ) & $\begin{array}{l}1,000 ; 5,000 ; \\
15,000\end{array}$ \\
\hline
\end{tabular}

After the definition of attributes the choice sets were constructed. Every alternative is built up by several combinations of attribute level values. The sum of the possible combinations is the full factorial; in this case it

\footnotetext{
${ }^{1}$ Implicit Price, trade-off ratio between the price and one of the other attributes
} 
counts 972 alternatives. It is impossible to complete this amount of choice tasks for the respondents so the fractional factorial was made to decrease significantly the number of alternatives. Due to this step 18 alternatives were remained and 9 choice sets were grounded on them. The sets contain two alternatives ('A' and 'B'), as well as an alternative 'neither' which represents the current energy systems' further existence. Figure 1 shows an example for choice set.

Figure 1: Example choice set

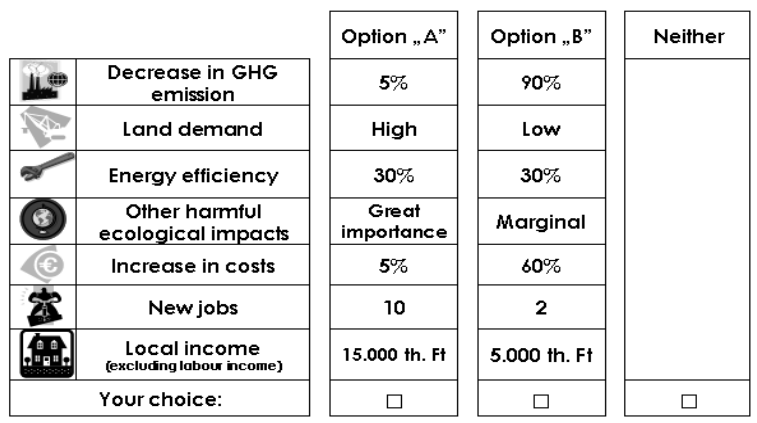

The questionnaire was designed in four parts. In the beginning, there are some easy warm-up questions regarding the knowledge and opinion of the respondent. The second part comprises the nine choice tasks. After these tasks, there are questions in which respondents are asked to state their attitude for dimension of the sustainable development. In the fourth - final - part, some socio-economic information about the participant is required.

In the current phase of the research, the survey is fulfilled on the population of experts. 117 Hungarian professionals were chosen by the following criteria: Experts must have serious publication in the topic of RES, environmental economics or environmental policy. We considered as experts also those professionals, who held a position in governmental units, universities or in serious NGOs - even without publication activity. An on-line survey service was used which was available between 11 and 28 march 2011. 38 surveys filled in were received in time. The examination of the experts' population was successful because of the many constructive, helpful proposals of the colleges which are very useful for the further surveys of students and the general population.

\section{RESULTS}

The survey results regarding to warm-up questions and the experts' attitude are obvious. 97.4\% of respondents heard about sustainable development yet and according to $95 \%$ of them would be important a higher portion of RES. Other answers are probably resulted by misunderstanding. The solution of the environmental and social problems is more serious and pressing (4.58 on scale of 1-5) than the economic problems (3.97) according to respondents' answers. The socio-economic data are less informative in the case of experts because they were examined by right of their knowledge.

The estimation results of our model are presented in Table 2. It shows that not all coefficients are significant at $0.1 \%$ level. However, the signs of every $\beta$ coefficient are consistent with our expectation. The positive signs imply that the experts are more likely to choose a technology which is decreasing emissions, more efficient, creating new jobs and realizing local incomes. The attributes with negative sign are connected with harmful impacts. The signs imply the changes in the utility of respondents. For instance, when costs are increasing, the utility is decreasing. Contrarily, the higher the decrease in GHG emission is, the higher the probability of choosing that alternative becomes: thus, the utility connected with this attribute.

Table 2

Estimation results of the $C L$ model

\begin{tabular}{|l|l|l|l|}
\hline & \multicolumn{1}{|c|}{$\beta$ coefficient } & exp. $\beta$ coef. & 0.3737 \\
\hline ASC & -0.00324 & 0.997 & 0.0262 \\
\hline Decrease in GHG emission & $0.15785^{*}$ & 1.171 & 0.1003 \\
\hline Land demand & -0.12652 & 0.881 & 0.0541 \\
\hline Energy efficiency & 0.03993 & 1.041 & 0.0986 \\
\hline Other harmful ecological impacts & $-0.47129 *$ & 0.624 & 0.0456 \\
\hline Increase in costs & $-0.18152^{*}$ & 0.834 & 0.1424 \\
\hline New jobs & 0.08954 & 1.094 & 0.1937 \\
\hline Local income & 0.28547 & 1.330 & \\
\hline
\end{tabular}

* significant at $0.1 \%$ level

Likelihood ratio test $=162$ on $8 \mathrm{df}, \mathrm{p}=0, \mathrm{n}=1026$, number of events $=342$,

Exp. $\beta$ coefficient $=\mathrm{e}^{\beta}$ 
The exponential $\beta$ coefficients report the changes in utility value of respondents. In the case of nominal leveled attributes, the exp. $\beta$ coef. implies how much is the change in utility derived from the variation of levels for instance by other harmful ecological impacts. If it alters from 'marginal' to 'great importance' level than the utility value is decreased $37.6 \%$ (1-0.624). In the case of percentage leveled attributes the exp. $\beta$ coef. means the change of utility in percents (e. g. $16.6 \%$ decrease is derived by $10 \%$ increase in costs).

The $\beta$ coefficient reports about the role of each attribute in the choice of the population as well as in the utility (see equation (4)). The highest $\beta$ value is observable by other harmful ecological impacts (-0.47129). $27.5 \%{ }^{2}$ of utility value is derived by eliminating these impacts in case of RES based technologies. Also high level of utility $(21.1 \%)$ is connected with the local income unfortunately this attribute's $\beta$ is not significantly estimated. The local income is more notable in point of sustainability then the increase in costs which serves only the $13.4 \%$ of utility. The role of decreasing GHG emissions is moderate $(11.7 \%)$. However, the low $\beta$ coefficients by energy efficiency as well as employment are surprisingly $(3.0 \%$ and $6.6 \%$ of utility) and not consistent with governmental policies.

\section{CONCLUSIONS}

The approach of the sustainability in the case of RES based technologies was calculated according to Hungarian experts. The elimination of harmful ecological impacts - emissions and others - would be the most relevant, the 'weight' of these attributes together gives almost the half of derived utility (46.4\%). The technological parameters, land demand and energy efficiency are less notable $(12.4 \%)$. Surprisingly the utility connected with local income is more then triple of the utility of new jobs. The $\beta$ value of local income is much higher then the cost attributes'. We conclude that the significance of local recourses' utilization is implied even at the expense of increasing investment and operation costs. The result of the survey can summarize as follows. According to experts, the elimination of harmful environmental impacts and the increase of local incomes are the key aspects to sustainable energy management.

\section{REFERENCES}

Bennett, J.-Blamey, R. (Eds.). (2001): The Choice Modelling Approach to Environmental Valuation. Edward Elgar. Cheltenham, 287 p. Bergmann, A.-Hanley, N.-Wright, R. (2004): Valuing the attributes of renewable energy investments. Energy Policy, 34. pp. 1004-1014.

del Rio, P.-Burguillo, M. (2008): Assessing the impact of renewable energy deployment on local sustainability: towards a theoretical framework. Renewable \& Sustainable Energy Reviews, 12. pp. 1325-1344.

del Rio, P.-Burguillo, M. (2009): An empirical analysis of the impact of renewable energy deployment on local sustainability. Renewable \& Sustainable Energy Reviews, 13. pp. 1314-1325.

Evens, A.-Strezov, V..Evans, T. J. (2009): Assessment of sustainability indicators for renewable energy technologies. Renewable \& Sustainable Energy Reviews, 13. pp. 1082-1088.

Gács I. (2010). A szélenergia-termelés támogatása. Elektrotechnika. 1. pp. 5-7.

Krajnyik Zs. (2008): Környezeti javak pénzbeli értékelése Magyarországon és Szlovákiában a feltételes választás módszerének alkalmazásával. PhD értekezés. Budapesti Corvinus Egyetem. 169 p.

$\mathrm{Ku}$, S.-Yoo, S. (2010): Willingness to pay for renewable energy investment in Korea: A choice experiment study. Renewable and Sustainable Energy Reviews, 14. pp. 2196-2201.

Longo, A.-Markandya, A.-Petrucci, M. (2008): The internalization of externalities in the production of electricity: Willingness to pay for the attributes of a policy for renewable energy. Ecological Economics, 67. pp. 140-152.

Lukács G. S. (2009): Megújuló energia és vidékfejlesztés. Budapest: Szaktudás Kiadó Ház. 265 p.

Mayerhoff, J.-Liebe, U.-Hartje, V. (2009): Benefits of biodiversity enhancement of nature-oriented silviculture: Evidence from two choice experiments in Germany. Journal of Forest Economics, 15. pp. 37-58.

Rideg A.-Deutsch N.-Torjai L. (2009a): Biogázüzem telepítésének többszempontú értékelése. Energiagazdálkodás, 3. pp. 26-29.

Rideg A.-Deutsch N.-Torjai L. (2009b): Háztartási hasznosítású napkollektoros és hőszivattyús beruházás többszempontú értékelése. Magyar Épületgépészet, 7-8. pp. 6-10.

Roe, B.-Teisl, M. F.-Levy, A.-Russell, M. (2001): US consumers' willingness to pay for green electricity. Energy Policy, 29. pp. 917-925.

Varga K.-Homonnai G. (2009): Munkahelyteremtés zöld energiával. Budapest: Energia Klub. 17 p.

Ulbert J.-Takács A. (2007): Energetikai beruházások társadalmi hasznosságának mérése. Via Futuri 2007. Pécs.

\footnotetext{
${ }^{2} \beta_{\mathrm{i}} / \sum|\beta|$
} 